DOI: 10.1136/ANNRHEUMDIS-2019-EULAR.5333

\section{AB1306 PILOT STUDY OF ADHERENCE IN PATIENTS WITH RHEUMATOLOGICAL DISEASES AUTOIMMUNE}

E.C. Cervantes Pérez ${ }^{1}$, Jose Ramón Maneiro Fernández ${ }^{1}$, Begoña Moreira ${ }^{1}$, José Antonio Mosquera Martínez ${ }^{2}$, Natalia Bea ${ }^{1}$, Susana Romero-Yuste ${ }^{1}{ }^{1}$ Complexo Hospitalario Universitario de Pontevedra, Rheumatology Service, Pontevedra, Spain; ${ }^{1}$ Complexo Hospitalario Universitario de Pontevedra, Rheumatology Service, Pontevedra, Spain

Background: Data on adherence in patients with autoimmune rheumatological diseases are limited.

Objectives: To analyze the adherence to treatment in patients with autoimmune rheumatological diseases.

Methods: A cross-sectional study was performed in patients from the Complexo Hospitalario Universitario de Pontevedra with diagnosis of systemic lupus erythematosus (SLE), Sjögren's Syndrome (SS) and Systemic Sclerosis (SE).

The patients filled an anonymous survey that included data about demographic, diagnosis and treatment. Adherence to treatment was assessed using the Spanish Compliance Questionnaire in Rheumatology (sCQR). [1] Likewise, a linear regression analysis was carried out in order to identify factors related to adherence to treatment. A significant value was considered as $p<0.05$. Stata version 11.1 (Stata/IC 11.1 for Windows, StataCorp LP, College Station, TX) was used to perform all analyzes.

Results: A total of 44 patients participated in the study, although $90.9 \%$ of the surveys carried out could be used for the analysis. A total of 25 (62.5\%) SLE, 9 (22.5\%) SS and 6 (15.0\%) SE patients participated. There were $82.5 \%$ of women and the mean age was $48.9 \pm 12.8$ (See Table 1). According to the SCQR $82.5 \%$ were compliant patients. None of the studied variables was associated with the adherence rate: sex ( $p$ $=1.000)$, age $(0.134)$, time of evolution $(p=1.000)$, level of education $(p=0.677)$, marital status $(0.392)$, illness $(p=1.000)$, number of drugs ingested per day $(p=0.873)$, treatment with steroids $(p=0.679)$ or antimalarials $(p=1.000)$.

Conclusion: The adherence rate in our cohort was $82.5 \%$ higher than previously reported in other studies. [2,3] The SCQR could be a useful and easy-to-apply tool for the study of adherence in these patients.

\section{REFERENCES}

[1] Salgado E, Maneiro Fernandez JR, Souto Vilas A, Gomez-Reino JJ. Correction to: Spanish transcultural adaptation and validation of the English version of the compliance questionnaire in rheumatology. Rheumatol Int 2018.

[2] Feldman CH, Yazdany J, Guan H, Solomon DH, Costenbader KH. Medication nonadherence is associated with increased subsequent acute care utilization among Medicaid beneficiaries with systemic lupus erythematosus. Arthritis Care Res 2015;67:1712-21.

[3] Alsowaida N, Alrasheed M, Mayet A, Alsuwaida A, Omair MA. Medication adherence, depression and disease activity among patients with systemic lupus erythematosus. Lupus. 2018 Feb;27(2):327-332. doi: 10.1177/ 0961203317725585 . Epub 2017 Aug 21. PubMed PMID: 28825347.

Table 1. Clinical and sociodemographic characteristics of the patients

\begin{tabular}{|c|c|c|c|}
\hline & $\mathrm{N}=40$ & & $\mathrm{~N}=40$ \\
\hline $\begin{array}{l}\text { Age (years), mean, } n \\
(\%)\end{array}$ & $\begin{array}{c}48.9 \\
\pm 12.8\end{array}$ & Evolution, $\mathrm{n}(\%)$ & \\
\hline Sex (women), n (\%) & $40(82.5)$ & $\cdot<1$ year & $2(5.0)$ \\
\hline Marital status, n (\%) & & - 1-2 years & $3(7.5)$ \\
\hline - Single & $14(35.0)$ & - 2-5 years & $8(20.0)$ \\
\hline - Married & $25(62.0)$ & $\cdot>5$ years & $\begin{array}{c}27 \\
(67.5)\end{array}$ \\
\hline - Widows/Widower & $1(2.5)$ & $\begin{array}{c}\text { - Number of drugs ingested per day, } \mathbf{n} \\
(\%)\end{array}$ & \\
\hline Education, $\mathrm{n}(\%)$ & & $\cdot 1$ & $9(22.5)$ \\
\hline - None & $3(7.5)$ & $\cdot 2$ & $5(12.5)$ \\
\hline - Primary & $13(32.5)$ & $\cdot 3$ & $\begin{array}{c}11 \\
(27.5)\end{array}$ \\
\hline - Secondary & $10(25.0)$ & $\cdot 4$ & $4(10.0)$ \\
\hline - Superior/University & $1(2.5)$ & $\cdot 5$ & $2(5.0)$ \\
\hline Occupation, n (\%) & & $\cdot>5$ & $9(22.5)$ \\
\hline - Student & $1(2.5)$ & Treatments, $\mathbf{n}(\%)$ & \\
\hline - Unemployed & $2(10.0)$ & . Antimararial & $\begin{array}{c}21 \\
(52.5)\end{array}$ \\
\hline - Active & $20(50.0)$ & Steroids & $\begin{array}{c}14 \\
(35.0)\end{array}$ \\
\hline - Job loss & $1(2.5)$ & Methotrexate & $5(12.5)$ \\
\hline - Retirement & $8(20.0)$ & Azathioprine & $1(2.5)$ \\
\hline
\end{tabular}

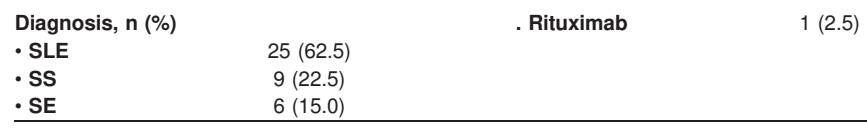

Disclosure of Interests: None declared DOI: 10.1136/annrheumdis-2019-eular.6416

\section{AB1307 STUDY OF CONCORDANCE AND EQUIVALENCE AMONG BARTHEL, LAWTON, HAQ AND BASFI QUESTIONNAIRES IN RHEUMATOID AND SPONDYLOARTHRITIS PATIENTS}

Miguel Angel Belmonte Serrano, Antonio Lozano Saez, Arantxa Conesa, Maria Copovi Moya. Hospital General Universitari de Castelló, Rheumatology, Castelló de la Plana, Spain

Background: Assessment of functional capacity of patients is usually performed using disease-specific questionnaires for rheumatoid arthritis (HAQ) and for axial spondyloarthropathies (BASFI). However, frequently non disease-specific, general indexes such as Barthel and Lawton-Brody (LB) are used to establish disability in legal environtments and in emergency rooms. Few studies have compared specific vs. generic questionnaires in rheumatic patients (1)

Objectives: To assess the equivalence between disability questionnaires of generic type, applicable to general population and various diseases (Barthel and LB), with specific questionnaires for rheumatic diseases (HAQ and BASFI).

Methods: A cross-sectional study was conducted in consecutive outpatients with inflammatory rheumatic diseases (rheumatoid arthritis, psoriatic arthritis, spondyloarthropathies) in usual daily clinical practice in a rheumatology clinic of a tertiary hospital.

The patients self-completed the questionnaires (Barthel, LB, HAQ, and $\mathrm{BASFI}$ ) in a single session. $\mathrm{HAQ}$ was only filled by peripheral arthritis patients, while BASFI was only given to spondyloarthropathy subjects. Scores were also computed for SDAI, DAS28 and BASDAI in most patients. Intraclass correlation was used to measure concordance between questionnaires.

Results: A total of 214 patients where studied. There was good correlation between the scores of the indexes studied, especially between the two general questionnaires $(R=0.45 p<0.01)$. We observed a high ceiling effect in the scores of both Barthel, $(70 \%$ of patients obtained values> 95 over a maximum of 100) and Lawton-Brody $(60 \%$ had values $>$ 23 over a maximum of 24) tests. The disease-specific questionnaires showed a less skewed distribution. The agreement between Barthel's and Lawton's tests was significant when measured by the intraclass correlation $(R=0.48 p<0.01)$. However, we could not find any significant correlation between the generic questionnaires and the $H A Q$ questionnaire or the BASFI $(R<0.3)$.

Conclusion: The Barthel and Lawton-Brody indices show an important ceiling effect in rheumatic patients, and seem to evaluate dimensions of health other than rheumatic questionnaires such as $\mathrm{HAQ}$ and BASFI, and thus they are not interchangeable. This point must be taken into account when performing medicolegal or emergency room assessments. Our result is in line with other previous studies(1)

\section{REFERENCE}

[1] Zochling J, Stucki G, Grill E, Braun J. A comparative study of patientreported functional outcomes in acute rheumatoid arthritis. J Rheumatol 2007;34(1):64-9.

Disclosure of Interests: None declared

DOI: 10.1136/annrheumdis-2019-eular.5982

\section{AB1308 1 FAILURE TO BIOLOGICAL THERAPY: WHEN TO EXPECT IT?}

rim dhahri ${ }^{1}$, Salma Athimni ${ }^{1}$, Maroua Slouma ${ }^{1}$, Leila Metoui ${ }^{1}$, Imen Gharsallah ${ }^{1}$, Bassem Louzir ${ }^{1}$, Maroua Meddeb ${ }^{2}$, Mahdi Dridi ${ }^{2} .{ }^{1}$ Military Hospital, rheumatology, Teboulbou, Tunisia; ${ }^{2}$ Military Hospital, pharmacology, Teboulbou, Tunisia

Background: Using Biologic agents, has considerably improved the treatment of inflammatory diseases.But it is associated to thecapacity of inducing an immune response in patients that could result in unwanted adverse events or treatment failure. 
Objectives: The aim of this work was to compare the clinical and biological response to biotherapy with the presence of ADA and the residua dose rate.

Methods: We analysed the medical records of 69 patients treated with biotherapy between September 2017 and October 2018.3 pathologies were considered: rheumatoid Arthritis (RA) diagnosed by ACR/EULAR 2009 criteria, Spondylarthritis (SPA) according to Assessment of Spondylarthritis international Society (ASAS) And crohn'sdisease (CD) classified upon the 2006' Montreal classification. We did search the presence of anti-bodyanti-drugs (ADA) and the residual dose for the following therapies: Etanercept (ETN),Infliximab (IFX), Adalimumab (Ada)or Rituximab (RTX).

Results: The mean age was $43.33 \pm 11.4$ year. The sexratio M/F was 1.57 .

Regarding the RA: they were 13 patients. 10 had positive (ACPA) and seven positive (RF). All the patients had an initial treatment by conventional synthetic disease modifying antirheumatic drugs(csDMARDs) before moving to bDMARDs. 14 were in concomitant disease modifying therapy. The DAS28-ESR average was at 4.12 [2.67 à 5.79]. we found positive ADA in only one patient analysis. There were 8 responding versus five non-responding patients,according to the clinical and biological evaluation of disease activity.

28 patients were In the SPA group: 13 with an axial spondyloarthritis $14 \%$ had the HLAB 27. It was an active disease in 15 cases. ASDASCRP average was $4,87 \pm 0,17[4.7 ; 5]$. The received biotherapy was IFX $50 \%$, ETN $28.6 \%$ and Ada 21.4\%. 10 patients had a positive ADA and 8 of them had a rate superior to 100 UI. 19 patients were considered as non-Responding.

In the CD group, 28 patients were enrolled. All oft hem had a previous immunosupressor treatment. Same patients in association with biotherapy. It was positve ADA in 7 cases. And 7 patients were non-responding to the treatment.

The residual dose of drugs was calculated for each drug and it is explained in the following table :

\begin{tabular}{lcccccccc}
\hline & \multicolumn{1}{c}{ IFX } & \multicolumn{2}{c}{ Ada } & & ETN & \multicolumn{2}{c}{ RTX } \\
\hline $\begin{array}{l}\text { High } \\
\begin{array}{l}\text { Residual } \\
\text { dose }\end{array}\end{array}$ & $\% 0 \%$ & 21 & $52.9 \%$ & 9 & $90.9 \%$ & 10 & $66.7 \%$ & 4 \\
$\begin{array}{l}\text { Low residual } \\
\text { dose }\end{array}$ & $40)$ & 14 & $47.1 \%$ & 8 & $9.1 \%$ & 1 & $33.3 \%$ & 2 \\
\hline
\end{tabular}

Positve ADA was associated with therapy failure in all type of biotherapy $(p=0.001)$. A low residual dose was associate to therapy failure only in the case of IFX ( $p=0.005)$.

In multivariate analyses, the predictive factors associated with therapeutic failure were : positive $\operatorname{ADA}(\mathrm{p}=0.008)$ and advanced age at diagnosis, bellow 30 years old age $(p=0.020)$. Hosmer index $=0.452$.

Conclusion: Immune response induced in patients treated with biotherapy can be quantified now thanks to ADA dosage and the residual dose assessment.

\section{REFERENCES}

[1] Kristensen LE, Kapetanovic MC, Gülfe A, Söderlin M, Saxne T, Geborek P. Predictors of response to anti-TNF therapy according to ACR and EULAR criteria in patients with established RA: results from the South Swedish Arthritis Treatment Group Register. Rheumatology (Oxford). 2008;47:495-9

[2] Lanfant-Weybel K, Lequerré T, Vittecoq O. Anti-TNF alpha dans le traitement de la polyarthrite rhumatoïde et de la spondylarthrite ankylosante. Presse Med. 2009;38:774-87.

Disclosure of Interests: None declared DOI: 10.1136/annrheumdis-2019-eular.8230

\section{AB1309 QUANTIFICATION OF MINIMAL RESIDUAL DOSE ASSOCIATED WITH BIOLOGICAL THERAPEUTIC RESPONSE ANTI DRUG ANTI BODIES: ARE THEY ALL NEUTRALIZING?}

Salma Athimni ${ }^{1}$, rim dhahri ${ }^{1}$, Maroua Slouma ${ }^{1}$, Leila Metoui ${ }^{1}$, Imen Gharsallah ${ }^{1}$, Bassem Louzir ${ }^{1},{ }^{2,2}$ Maroua Meddeb ${ }^{2,2}$, Mahdi Dridi'. ${ }^{1}$ Military Hospital, rheumatology, Teboulbou, Tunisia; ${ }^{2}$ Military Hospital, pharmacology, Teboulbou, Tunisia

Background: The use of biological was associated to the capacity of inducing an immune response in patients that could neutralize the drug.
The anti-body anti-drug (ADA) assay was a revolutionary tool to prevent treatment failure.

Objectives: The aim of this work was to asses if the presence of ADA in patients system is sufficient to preduct failure and indicates the switch of treatment.

Methods: We enrolled 69 patients treated with biotherapy between September 2017 and October 2018. 3 pathologies were considered: rheumatoid Arthritis (RA) diagnosed by ACR/EULAR 2009 criteria, Spondylarthritis (SPA) according to Assessment of Spondylarthritis international Society (ASAS) And crohn's disease (CD) classified upon the 2006'Montreal classification. We did search the presence of anti-body antidrugs (ADA) and the residual dose for the following therapies: Etanercept (ETN), Infliximab (IFX), Adalimumab (Ada) or Rituximab (RTX).

Results: The mean age was $43.33 \pm 11.4$ year. The sex ratio M/F was 1.57. there were 13 patients with RA, 28 SPA and 28 CD. The Majority of patients were receiving IFX $50.7 \%(n=35)$ with same doses. There were 20 responding versus 15 non-respondingpatients. $40 \%$ of them had a high residual dose. Regarding Ada 24.6\% $(n=17)$. There were 9 nonresponding patients and low residual doses were found in $47.1 \%$. 11 patients were using ETN. The ADA was positive in only one patient who was non-responding and having a low residual dose.

Concerning the RTX, it was used for 6 patients. The ADA was negative in all patients. Two non-responding cases having a low residual dose. The following table explains the repartition of patients according to ADA rates:

\begin{tabular}{|c|c|c|c|}
\hline & & $\begin{array}{c}\text { ADA } \\
\text { Positifs }\end{array}$ & $\begin{array}{c}\text { ADA } \\
\text { Négatifs }\end{array}$ \\
\hline \multirow[t]{2}{*}{ IFX } & $\begin{array}{l}\text { Responding } \\
\text { patients }\end{array}$ & 4 & 16 \\
\hline & Non-responding & 9 & 6 \\
\hline \multirow[t]{2}{*}{ ETN } & $\begin{array}{l}\text { Responding } \\
\text { patients }\end{array}$ & 0 & 6 \\
\hline & Non-responding & 1 & 4 \\
\hline \multirow[t]{2}{*}{ Ada } & $\begin{array}{l}\text { Responding } \\
\text { patients }\end{array}$ & 0 & 8 \\
\hline & Non-responding & 4 & 5 \\
\hline \multirow[t]{2}{*}{ RTX } & $\begin{array}{l}\text { Responding } \\
\text { patients }\end{array}$ & 0 & 4 \\
\hline & Non-responding & 0 & 2 \\
\hline
\end{tabular}

Positive ADA was associated with therapy failure in all type of biotherapy $(p=0.001)$. A low residual dose was associate to therapy failure only in the case of IFX $(p=0.005)$.

Positive ADA was associated to a low rate of residual dose in the case of IFX and Ada.

This association couldn't be evaluated for RTX (none) and ETN (just one positive rate).

Conclusion: The ADA assay is a revolutionary tool allowing the evaluation of treatment response but it cannot be considered without the clinical assessment of patient. The evaluation residual dose should be concomitant to valorize and guide the therapeutic decision

\section{REFERENCES}

[1] Kristensen LE, Kapetanovic MC, Gülfe A, Söderlin M, Saxne T, Geborek $P$. Predictors of response to anti-TNF therapy according to ACR and EULAR criteria in patients with established RA: results from the South Swedish Arthritis Treatment Group Register. Rheumatology (Oxford) 2008:47:495-9

[2] Lanfant-Weybel K, Lequerré T, Vittecoq O. Anti-TNF alpha dans le traitement de la polyarthrite rhumatoïde et de la spondylarthrite ankylosante. Presse Med. 2009;38:774-87.

Disclosure of Interests: None declared DOI: 10.1136/annrheumdis-2019-eular.8271

\section{AB1310 PROSPECTIVE USE OF THE GLUCOCORTICOID TOXICITY INDEX (GTI) IN A COHORT OF VASCULITIS PATIENTS}

Lisa Ehlers ${ }^{1}$, Edgar Wiebe ${ }^{1}$, Desiree Freier ${ }^{1}$, Sandra Hermann ${ }^{1}$, Eli Miloslavsky ${ }^{2}$, Yuqing Zhang ${ }^{2}$, Frank Buttgereit ${ }^{1}$, John $\mathrm{H}$. Stone ${ }^{2} .{ }^{1}$ Charité - Universitätsmedizin Berlin, Berlin, Germany; ${ }^{2}$ Division of Rheumatology, Allergy, and Immunology, Medicine, Boston, United States of America

Background: The Charite Rh-GIOP is a prospective study of disease- \& bone-related data from patients with chronic inflammatory diseases treated with glucocorticoids (GCs). The Glucocorticoid Toxicity Index app (GT 2.0) measures changes in GC-associated morbidity. The GTI captures 